\title{
YARGITAY KARARLARI IŞIĞINDA HAKARET SUÇLARINDA ÖZEL TAHRİK HALLERİ (TCK m. 129)
}

\author{
Special Provisions on Unjust Provocation in Offenses of Defamation \\ in the Light of the Court of Cassation Case Law
}

Yeşim GARİPOĞLU ÖZEN*

\begin{abstract}
ÖZET
Ceza hukukunda haksız tahrik, suça etki eden bir hafifletici nedendir. 5237 sayılı Türk Ceza Kanunu'nun 29. maddesinde düzenlenen haks1z tahrik, bütün suçlar bakımından uygulanabilen ortak bir suça etki eden nedendir. Haksız tahrikin ilk şartı, suç mağdurunun haksız bir fiilinin varlığıdır. İkinci şart, bu haksız fiilin failde hiddet veya şiddetli elem yaratmasıdır. Diğer şart ise, işlenen suç ile öfke hali arasında nedensellik bağının bulunmasıdır. Haksız tahrikin kasten işlenen suçlarla bağdaşabileceği konusunda bir tereddüt bulunmamaktadır. Bununla birlikte taksirli suçlar bakımından haksız tahrikin uygulama alanı bulup bulamayacağı tartışmalıdır. Türk Ceza Kanunu'nun hakaret suçuna ilişkin özel hükümlerinde özel tahrik düzenlemelerine rastlamak mümkündür. Böyle olunca özel normun önceliği ilkesi gereği bu hükümler öncelikle uygulanmak durumundadır. Kanunun özel hükümlerinde düzenlenen bu tahrik hallerinin, genel haksız tahrik hallerinden ontolojik olarak herhangi bir farkı bulunmamaktadır. Hakaret suçları özelinde uygulama alanı bulan TCK m. 129, bu bağlamda Yargıtay kararlarının da ışığında haksız tahrikin özel bir hali olarak inceleme konusu yapılmıştır.
\end{abstract}

Anahtar Kelimeler: Haksız Tahrik, Haksız Tahrikin Özel Düzenlemesi, Türk Ceza Kanununda Haksız Tahrik.

Makalenin Geliş Tarihi: 06.07.2021, Makalenin Kabul Tarihi: 18.08.2021.

Ankara Bölge Adliye Mahkemesi 6. Ceza Dairesi Başkanı, (ymozen@gmail.com, ORCID: 0000-0003-3478-3958) 


\section{ABSTRACT}

Unjust provocation, for the Turkish criminal law, is a mitigating cause. Unjust provocation, regulated in the Article 29 of the Turkish Penal Code No. 5237, is the common cause which affects the crime that can be applied in terms of all crimes. The first condition of unjust provocation is the existence of a wrongful act of the victim. The second condition is that this wrongful act creates anger or severe pain. The other condition is that there is a cause-effect link between the crime committed and the state of anger. It is clear that unjust provocation can be compatible with intentional crimes. However, it is controversial whether unjust provocation can be applied in terms of negligent crimes. It is possible to find special provocation regulations in the special provisions of the Turkish Penal Code regarding to the crime of insult. These regulations have no ontological difference from general provocation regulations. Thus, due to the lex specialis principle, these provisions must be applied firstly. Article 129 of Turkish Penal Code, which is applied in cases of defamation, is examined in this study with reference to the Court of Cassation case law.

Keywords: Unjust Provocation, Special Provision on Unjust Provocation, Unjust Provocation in the Turkish Penal Code.

I. Genel Olarak Haksız Tahrik, II. Haksız Tahrikin Hakaret Suçuna Özgü Bir Hali Olarak Yer Alan TCK m. 129 Düzenlemesi, A. TCK m. 129/1 Hükmünde Yer Verilen Düzenleme Bağlamında Suçun Haksı Bir Fiile Tepki Olarak İslenmesi , B. TCK m. 129/2 Hükmünde Yer Verilen Düzenleme Bağlaminda Suçun Kasten Yaralama Suçuna Tepki Olarak Işslenmesi, C. TCK m. 129/3 Hükmünde Yer Verilen Düzenleme Bağlamında Hakaret Suçunun Karşılıklı Olarak Işlenmesi

\section{GENEL OLARAK HAKSIZ TAHRİK}

Suçun bir unsuru olmayan ve suçun varlığını da etkilemeyen bununla birlikte suçun ağırlığına etki eden nedenler, doktrinde, "suçun halleri" terimi ile ifade edilmektedir ${ }^{1}$. Bununla birlikte bu haller isnat yeteneğini kaldıran veya azaltan nedenlerden ${ }^{2}$ ya da cezalandırılabilme şartlarından da değildirler.

1 Sulhi DÖNMEZER - Sahir ERMAN, Nazari ve Tatbiki Ceza Hukuku (Genel Kısım) C. II, Sulhi Garan Matbaası, B. 11, İstanbul 1997, s. 339 vd.

2 Karş. Mehmet Emin ARTUK - Ahmet GÖKCEN, Ceza Hukuku Özel Hükümler, Adalet 
Mülga 765 sayılı TCK ve onun mehazı olan ve doktrinde de Zanardelli kanunu olarak anılan kanunda, haksız tahrike (m. 51) cezai ehliyeti ve bunu kaldıran veya hafifleten nedenler arasında yer verildiği ve bununla birlikte suçların yanındaki düzenlemelerde o suçu ağırlaştıran ve hafifleten nedenlerin düzenlendiği görülmekteydi.

Yürürlükteki 5237 sayılı TCK'nın da 765 sayılı Kanundan bu bağlamda pek de farklı olmadığ ${ }^{3}$ görülmekle birlikte haksız tahrike ilişkin düzenlemeye genel hükümler arasında m. 29'da "Ceza Sorumluluğunu Kaldıran ve Azaltan Nedenler" başlığı altında yer verilmekte; TCK m. 62'de ise takdiri indirim nedenlerinin düzenlendiği görülmektedir.

Anılan düzenleme TCK m. 29'da "haksız bir fiilin meydana getirdiği hiddet veya şiddetli elemin etkisi altında suç işleyen" ile hüküm altına alınmaktadır. Böyle olunca, bu kurumun genel ve kanuni bir hafifletici neden olduğu görülmektedir ${ }^{4}$.

Haksız tahrik kurumunun esasının objektif, sübjektif ve karma teoriyle açıklandığı görülmektedir. Buna göre objektif teoride, faile yönlendirilen tahrikin haksızlığından yola çıkılmakta; böyle olunca tahrik fiili daha ön planda yer almaktadır. Sübjektif teoriye göre ise failde meydana gelen elem ve hiddetten hareketle bireysel/psikolojik bir değerlendirme yapılmaktadır ${ }^{5}$. $\mathrm{Bu}$ iki düşüncenin eleştirisinden doğan karma teoride savunulan görüş ise, "objektif ve sübjektif teorilerin ortaya koyduğu çözümleri birbirinden ayırmak güçtür, o halde hem failin psişik halini hem de tahrik fiilinin kendisini birlikte ele almak gerekir" şeklindedir ${ }^{6}$.

Haksız tahrik düşüncesinin temelinde haksız bir davranış sergilen birisinin, bir diğer kimseyi kışkırtıp onu öfke ve hiddet altına sokarak bir suçu işlemeye (örneğin, hakaret, sövme, iftira, yaralama vb.) tahrik etmesi durumunda tahrik edilen kimsenin bu suç nedeniyle verilecek cezasının hafifletilmesinin altında "hakkaniyet" düşüncesinin yattığı ifade edilmektedir. Böyle olunca, haksız tahrik suçu hafifleten öznel bir neden olmaktadır?.

Yayınevi, Ankara 2017, s. 533.

DEMİRBAŞ, Timur, Haksız Tahrik, Seçkin Yayınevi, Ankara 2021, s. 114.

4 DÖNMEZER - ERMAN, Nazari ve Tatbiki Ceza Hukuku (Genel Kisım), s. 364.

5 Veli Özer ÖZBEK - Koray DOĞAN - Pınar BACAKSIZ - İlker TEPE, Türk Ceza Hukuku Genel Hükümler, Seçkin Yayıncılık, 11. Bask1, Ankara 2020, s. 413.

6 ÖZBEK - DOĞAN - BACAKSIZ - TEPE, Türk Ceza Hukuku Genel Hükümler, s. 412.

7 Zeki HAFIZOĞULLARI - Muharrem ÖZEN, Türk Ceza Hukuku Genel Hükümler, USA Yayınc1l1k, Ankara 2018, s. 367. 
Haksız tahrikten bahsedilebilmesi için, suç mağdurunun "haksız bir fiilinin" var olması gerekir ancak bu fiilin suç olmasının gerekmediği, hukuka aykırı olmasının yeterli olduğu ifade edilmektedir ${ }^{8}$. Buna örnek olarak "alacaklının herkesin önünde borçludan alacağını istemesi" davranışı gösterilmekte, bu davranışın hukuka aykırı bir davranış olmadığı ifade edilmektedir. Denmektedir ki, borçlu, bu halde, öfke ve elem duyarak karşısındakine karşı bir yaralama fiili gerçekleştirirse, haksız tahrikten yararlanamaz zira kanun "haksız bir fiilden" söz bahsetmemekte, böyle olunca fiil ahlaka aykırı ancak hukuka aykırı değil ise muhatabın haksız tahrikten yararlanması mümkün görünmemektedir. Ancak doktrinde fiil ahlaka aykırıysa, hukuka aykırı olmasa bile haksız tahrik hükümlerinden yararlanılmasının önünde engel olmayacağı düşüncesine de rastlamak mümkündür.

Haksız fiilin varlığından bahsedilebilmesi için bir diğer şart fiilin muhatabında, mutlaka "hiddet veya şiddetli elem etkisi" meydana getirmesi gerekliliğidir. Burada düşünülmesi gerekenlerden biri, fiilin doğurduğu hiddetin ve elemenin etkisinin zamanıdır; böyle olunca, denmektedir ki, bu elem ve hiddetin etkisi geçtikten sonra suç işlenmesi halinde haksız tahrikten yararlanmak mümkün değildir9 .

TCK m. 29 ifadesinde, "haksız bir fiilin meydana getirdiği hiddet veya şiddetli elemin etkisi altında suç işleyen kimse"den bahsedilmekte ve salt "suç işleyen kimse" ifadesi kullanılmaktadır. Görüldüğü gibi bu konuda anılan düzenlemede, yönelinen süje konusunda bir açıklık olmadığ görünmektedir. Böyle olunca, denmektedir ki kanun koyucu fiilin yöneldiği kimsenin mutlaka haksız fiilin faili olmasını aramamaktadır ${ }^{10}$. Buradaki şart, nedensellik bağıdır. Böyle olunca, suçun üçüncü bir kişiye karşı işlenmesi halinde, fail haksız tahrikten yararlanır ${ }^{11}$ denmektedir.

Kanunun gerekçesinde kullanılan "bir suçun mağduruna yönelik gerçekleştirilen fiiller dolayısıyla fail haksız tahrikten yararlanmaz" ifadesi "bir suçtan mağdur olan kimseye karşı işlenen suçta, fiil yokluğundan ötürü zaten haksız tahrik mümkün değildir” düşüncesiyle eleştirilmektedir.

8 HAFIZOĞULLARI - ÖZEN, Genel Hükümler, s. 368.

9 Faruk EREM, Adalet Psikolojisi, AÜHF Yayınları, Yayın No. 161, 4. Bask1, Ajans - Türk Matbaas1, Ankara 1961, s. 78 vd.

10 Durmuş TEZCAN - Mustafa Ruhan ERDEM - Murat ÖNOK, Teorik ve Pratik Ceza Özel Hukuku, Seçkin Yayınevi, Ankara 2018, s. 626.

11 "Örneğin, cinsel saldırıya maruz kalan bir kız çocuğunun babası veya kardeși saldırganı öldürdüğünde, kuşkusuz haksız tahrikten yararlanacaktır.” Bkz. HAFIZOĞULLARI ÖZEN, Genel Hükümler, s. 368. 
Kasten işlenen suçlarda haksız tahrik söz konusu olabilmekte iken taksirli suçlar bakımından haksız tahrikin mümkün olup olmadığı hususunun tartışmalı olduğu bilinmektedir. Buna gerekçe olarak gösterilen hususlardan biri de gerek kanun metninde gerek kanun gerekçesinde bu konuda bir açıklık bulunmamasıdır. Gerçekten de kanunun düzenlemesinde veya gerekçesinde bu konuda bir ifadeye rastlamak mümkün değildir. Böyle olunca örneğin, sürücünün yolcuların hakaretine maruz kalması halinde dikkatini kaybederek trafikte kaza yapması ve bazı kimseleri yaralaması halinde haksız tahrikten yararlanılıp yararlanılamayacağı tartışılmaktadır. Böyle hallerde, bizce de, kanun açıkça yasaklamadığından, nadir de olsa haksız tahrik hükümlerinden yararlanılmasının önünde bir engel olduğunu söylemek mümkün görünmemektedir.

\section{HAKSIZ TAHRÍKİN ÖZEL BİR HALİ OLARAK TCK m. 129 DÜZENLEMESI}

TCK m. 129 düzenlemesinde kusurluluğu kaldıran veya azaltan özel nedenler olarak karşılıklı hakarete ve haksız fiile tepki olarak işlenen hakaret veya sövme şeklinde özel bir düzenlemesine yer vermektedir ${ }^{12}$. Her iki hal de haksız tahrikin hakaret suçuna özgü bir halini oluşturmaktadır ${ }^{13}$.

765 sayılı Kanunda bu husus 485. maddede üç fikra olarak düzenlenmekteydi ${ }^{14}$. Mehaz kanunda ise anılan hükümler 1889 tarihli Zanardelli Kanunu'nun 397. maddesinde yer almaktayd.

5237 sayılı TCK m. 129'da "haksız fiil nedeniyle veya karşılıklı hakaret" başlığı altında üç fikra olarak düzenlemeye yer verildiği görülmektedir. Anılan düzenlemeler aşağıdaki başlıklarda incelenecektir.

Kanun gerekçesinde "hakaret suçundan dolayı cezanın kaldırılması ve azaltılması bakımından üç ayrı duruma ilişkin hüküm bulunmaktadır" ifadesi

12 TEZCAN - ERDEM - ÖNOK, s. 624.

13 Zeki HAFIZOĞULLARI - Muharrem ÖZEN, Türk Ceza Hukuku Özel Hükümler Kişilere Karşı Suçlar, US-A Yayıncılık, Ankara 2016, s. 246 vd.

"İstanbul 18. Ağır Ceza Mahkemesince verilen kararın, 5237 Sayılı Türk Ceza Kanunun 129/1. maddesinde ki, "Hakaret suçunun haksız bir fiile tepki olarak işlenmesi halinde, verilecek ceza üçte birine kadar indirilebileceği gibi, ceza vermekten de vazgeçilebilir." hükmü uyarınca ... sanık hakkında Türk Ceza Kanunu'nun 129/1. maddesi hükmü tartışılmadan, itirazın kabulü yerine yazılı şekilde reddine karar verilmesinde," Yargıtay 4. CD, E. 2020/7050, K. 2020/19843, T. 15.12.2020 (kazanci.com).

14 Faruk EREM, Hakaret ve Sövme, Ankara Üniversitesi Hukuk Fakültesi Yayınları: No. 127, Güzel İstanbul Matbaas1, Ankara 1958, s. 54; Faruk EREM, Türk Ceza Hukuku Özel Hükümler, C. IV, 3. Bask1, Seçkin Kitabevi, Ankara 1985, s. 586 vd. 
kullanılmıştır. Birinci fikranın gerekçesinde, "mağdur kendi haksız hareketleriyle hakarete neden olmuş ise, haksız hareketinin ağırlığını göz önüne almak suretiyle hâkim, failin cezasını azaltabileceği gibi gerektiğinde tümüyle kaldırabilecektir" denmekte, ikinci fikranın gerekçesinde "ikinci fikraya göre, kişi kendisine karşı işlenen kasten yaralama suçuna tepki olarak işlediği hakaret suçu dolayısıyla cezalandırılamayacaktır" denmektedir. Üçüncü ve son fikranın gerekçesinde "karşllıklı hakaret hâllerinde hâkim, hangisinin neden olduğunu göz önünde bulundurarak taraflardan her ikisi veya birisi hakkında verilecek cezada indirim yapabileceği gibi, ceza vermekten tamamen sarfinazar da edilebilir." denmektedir.

Bilindiği gibi, TCK m. 129'un uygulandığ 1 durumlarda, TCK m. 29 hükmünün uygulanması yoluna gidilemez ${ }^{15}$. Nitekim Yargitay da bunu içtihat etmekte, örneğin, Yargıtay 4. Ceza Dairesi, 24.12.2020 tarihli bir kararında “... Hakaret suçunda haksız tahrik hükümlerinin uygulanmasına karar verilmiş ise de, özel hüküm olan ve daha lehe düzenleme içeren TCK'nın 129. maddesi yerine genel tahrik kurumuna ilişkin aynı Kanunun 29. maddesinin uygulanması bozmayı gerektirir" demektedir ${ }^{16}$.

TCK m. 129'un birinci fikrasında yer verilen düzenleme, haksız tahrikin hakaret suçunun varlığı halinde söz konusu olan haksız bir fiile tepki olarak işlenmesi, ikinci fikrasındaki düzenleme ise kasten yaralama suçuna karş1 TCK m. $125^{\prime}$ de öngörülen fiilin işlenmesidir ${ }^{17}$. Son olarak üçüncü

15 TEZCAN - ERDEM - ÖNOK, s. 625.

“... ve anılan Kanun'un 29. maddesinde yer alan "Haksız bir fiilin meydana getirdiği hiddet veya şiddetli elemin etkisi altında suç işleyen kimseye, ağırlaştırılmış müebbet hapis cezas1 yerine on sekiz yıldan yirmi dört yıla ve müebbet hapis cezas1 yerine on iki yıldan on sekiz yıla kadar hapis cezası verilir. Diğer hâllerde verilecek cezanın dörtte birinden dörtte üçüne kadarı indirilir." şeklindeki düzenlemeler nazara alındığında, somut olayda, hakaret suçundan mahkum edilen sanığın, eylemini haksız tahrik altında işlediğinin kabulüyle, 5237 Sayılı Kanun'un 29/1. maddesi uyarınca cezasından 1/4 oranında indirim yapıldığı ve sanığın neticeten 1.100,00 Türk lirası adli para cezasıyla cezalandırıldığı, ancak yapılan haksız tahrik uygulamasında, hakaret suçuna ilişkin özel hüküm olan ve daha lehe düzenlemeler içeren 5237 Sayılı Kanun'un 129. maddesinin uygulanması gerektiği gözetilmeden, aynı Kanun'un genel tahrik hükümlerine dair 29. maddesi uygulanmak suretiyle yazılı şekilde karar verilmesinde, isabet görülmemiştir." denilmektedir." Yargitay 18. CD, E. 2020/422, K. 2020/7387, T. 16.6.2020 (kazanci.com).

16 Yargitay 4. CD, E. 2020/19231, K. 2020/21468, T. 24/12/2020 (kazanci.com).

17 TEZCAN - ERDEM - ÖNOK, s. 624.

"Sanı̆̆ın eşinin hasta olması, doktor tarafindan yazılan 10 adet iğneden 6 adedinin yapıldığı 7. iğneyi yaptırmak için gittiklerinde katılanın reçeteyi sorduğu, yanlarında olmaması sonrasında deftere bakma ya da doktora danışma yoluyla vatandaşın işini görmesi gereken katılanın bunu yapmayarak 'Beni ilgilendirmez reçetenizi verin yoksa yapmam.' diyerek tartışmayı başlattığı, eşinin hastalığı ve iğnenin basit bir inceleme ile 
fikra düzenlemesi ise TCK' da "karş1lıklı hakaret" olarak ifadesini bulan ve doktrinde karşılıklı tahkir olarak anılan hususa ilişkin hüküm altına alınan normdur.

\section{A. TCK m. 129/1 Hükmünde Yer Verilen Düzenleme Bağlamında Suçun Haksız Bir Fiile Tepki Olarak İşlenmesi}

TCK m. 129/1, hakaret suçunun haksız bir fiile tepki olarak işlenmesi halinde "verilecek ceza üçte birine kadar indirilebileceği gibi ceza vermekten de vazgeçilebilir" şeklinde hüküm altına alınmıştır.

Mülga 765 sayılı Kanun döneminde, konuya ilişkin düzenleme "şahsı hakkında şiddet kullanılmasından dolayı hakaret eden kimsenin hareketi cezayı müstelzim değildir" ifadesinden ötürü eleştiri konusu yapılmakta, böyle olunca meşru müdafaa normunun bu hükmü karş1lamaya yeterli olduğu ifade edilmekteydi.

Bugün de geçerli olan iki farklı düşünceden birincisi, bunun meşru müdafaa olduğunu ${ }^{18}$, diğeri ise suça ve cezaya etki eden bir sebep olduğunu ${ }^{19}$ savunmaktadır.

Kurumun esasının meşru müdafaa düşüncesiyle açıklanamayacağını düşünenlere göre, meşru müdafaa ile benzeyen tek taraf "haksız bir saldırının" varlığıdır, bunun dışındaki unsurlar ortak görünmemektedir. Böylelikle, karşıllklı hakarette müdafaa durumunda olan "yalnız karşılık veren" taraf olmakta ve ancak her iki kişinin cezası kaldırılmaktadır; bunun yanında "hakaretin" bir müdafaa olduğunu saymamak gerekir"20. Karşı görüşte olan yazarlara göre ise, "şiddet kullananın tahkiri bir meşru müdafaa hali kabul edilmek" gerekir; çünkü şiddeti durdurabilmek için başka bir korunma imkanı bulunmayan kimsenin saldırganı tahkir etmesinde zorunluluk görünmektedir. Bu, tahkirin şiddet hareketini defetmeye yeterli olup olmaması ise meşru müdafaa kavramına yabancıdır. Çünkü meşru

vurulması mümkün iken bunu yapmayan katılanın haksız davranışı ile çıkan tartışma sonrasında sanı ̆̆ın eylemin gerçekleştiği anlaşıldığı halde TCK'nın 129. maddesinin uygulanması gerekirken uygulanmadan hüküm kurulması doğru olmamıştır." Yargıtay CGK, E. 2019/18-371, K. 2020/422, T. 15.10.2020 (kazanci.com).

18 Nevzat TOROSLU, Ceza Hukuku Özel Kısım, Savaş Yayınevi, Ankara 2019, s. 125.

19 TEZCAN - ERDEM - ÖNOK, s. 660; ÖZBEK-DOĞAN-BACAKSIZ, Özel Hükümler, s. 525; KOCA, Mahmut/ ÜZÜLMEZ, Mahmut, Türk Ceza Hukuku Özel Hükümler, Adalet Yayınevi, Ankara 2019, s. 496; ÖZEN, Mustafa, Ceza Hukuku Özel Hükümler Dersleri, Adalet Yayınevi, Ankara 2019, s. 493.

20 EREM, Hakaret ve Sövme, s. 54. 
müdafaada bakılacak husus başka bir korunma imkanının bulunmaması olup başvurulan korunma biçiminin tecavüzü defetme yeterli olması değildir ${ }^{21}$.

Bununla birlikte kanun koyucunun kullandığı "haksız bir fiil" teriminin doğru bir tercih olmadığı düşünülmektedir. Zira "haksız bir fiil" ancak borçlar hukukunda söz konusu olabilir; o halde buradan anlaşılması gerekenin "haksız fiill" olarak düşünülmesi bizce de doğru bir eleştiridir.

$\mathrm{Bu}$ halde, ilk haksız hareketin tayini de önem taşımaktadır. Yaralama fiilinde, haksız hareketin kimden geldiği şüpheli ise, "şüphe sanık lehinedir" kuralı gereği TCK m. 129/1'in uygulanması, en azından asgari seviyeden uygulanması gerekmektedir. Nitekim Yargitay da bir kararında “... Sanık ... hakkında ...'i yaralama ve ...'yı basit yaralamaya teşebbüs suçlarından kurulan hükümler yönünden; ilk haksız hareketin kimden kaynaklandığg şüpheye yer bırakmayacak şekilde belirlenemediğinde, ... TCK'nin 29 . maddesi gereğince asgari seviyede haksız tahrik hükümlerinin uygulanmasını gerektirdiği gözetilmeden hatalı indirim yapılması suretiyle eksik ceza tayini ... bozmayı gerektirir" diyerek ve doğru olarak, ilk haksız fiilin kimden geldiğinin tam olarak tespit edilemediği hallerde, şüphe sanık lehinedir kuralı gereği sanık lehine olarak TCK m. 129 hükmünün sanık hakkında asgari seviyeden uygulanması gerektiğini belirtmektedir ${ }^{22}$.

Sonuç olarak diğer başlıklarda da inceleneceği üzere, TCK m. 129'un birinci fikra hükmü bağlamında, bu fikra hükmünün uygulanabilmesi için ortada bir haksız fiilin olması ${ }^{23}$, bu haksız fiile karşı gerçekleştirilen fiilin

${ }^{21}$ Sahir ERMAN, Hakaret ve Sövme Suçları, İstanbul Üniversitesi Fen Fakültesi Döner Sermaye İşletmesi Prof. Dr. Nazım Terzioğlu Basım Atölyesi, 2. Baskı, İstanbul 1989, s. 221; Sahir ERMAN - Çetin ÖZEK, Ceza Hukuku Özel Bölüm Kişilere Karşı İşlenen Suçlar, Dünya Yayıncıllk, İstanbul 1995, s. 323.

22 Yargitay 3. CD, E. 2019/18254, K. 2020/3112, T. 17.2.2020 (kazanci.com).

23 “... Sanı̆̆ın aşamalarda "ben olay günü elimde çekiçle inşaatta tadilat yapıyordum, müştekinin eşimle bağırarak konuştuğunu bu molozları eşine söyle atmayacaksınız şeklinde sözler söylediğini duymam üzerine yanlarına koşarak gittim, elimdeki çekici çalıştığım yere bırakarak yanlarına gittim, daha önce eşime darp uyguladıkları için hemen koşarak gittim, eşimi oradan uzaklaştırdım telefon ile polisi aradım kesinlikle ben ve eşim küfür etmedik, çekiçle üzerine yürümedim, daha önce aramızda husumet olduğundan şikayetçi olmuş" şeklindeki savunması karşısında, olayın çıkış nedeni ve gelişmesi değerlendirilerek sonucuna göre TCK'nın 129, maddesinde düzenlenen haksız tahrik hükümlerinin uygulanıp uygulanmayacağının tartışılmaması ... bozmayı gerektirir.” Bkz. Yargitay 18. CD, E. 2019/10072, K. 2020/4564, T. 18.2.2020 (kazanci.com).

“...Sanığın sekiz yaşındaki oğluna yönelik yaralamaya teşebbüs olayı ile ilgili olarak mağdurların görev yapmakta oldukları jandarma karakolunda mağdur velisi sıfatıyla şikayetinin tespit edilmesinden sonra mağdur oğlunun ifadesinin tespiti için karakola gelen sanığın karakol komutanının karakol dışında görevde olması nedeniyle oğlunun ifadesinin 
hakaret olması ve bu fiilin haksız fiili gerçekleştiren kişiye yönelmiş olması gerekmektedir ${ }^{24}$.

\section{B. TCK m. 129/2 Hükmünde Yer Verilen Düzenleme Bağlamında Suçun Kasten Yaralama Suçuna Tepki Olarak İşlenmesi}

TCK m. 129/2 düzenlemesinde "bu suçun kasten yaralama suçuna tepki olarak işlenmesi halinde" kişiye ceza verilemeyeceği ifade edilmektedir. Kanun koyucu, görüldüğü üzere, kasten yaralama suçunu birinci fikradan daha farklı düşünerek ayrıca hüküm altına almıştır.

Kanunda yaralamanın derecesi bakımından belirli bir özellik aranmamıştır. Önemli olan, yaralama ve hakaret arasındaki nedensellik ilişkisinin tespitidir ${ }^{25}$.

Doktrinde bu madde ile ilgili olarak, örneğin 765 sayılı Mülga TCK m. 485/3 hükmü ile kıyaslandığında, önceki kanunda kanun koyucunun "şahsı hakkında şiddet kullanılmasından dolayı" ifadesini bilinçli bir şekilde tercih ettiği, çünkü bu kurumu yaralama suçuna özgülemekten imtina ettiği ifade edilmekteydi.

Bu konuya ilişkin kanun gerekçesinde bir nedene rastlanılmamaktadır. Kanun koyucu gerekçede "kişi kendisine karşı işlenen kasten yaralama suçuna tepki olarak işlediği hakaret suçu dolayısıyla cezalandırılamayacaktır" ifadesini kullanmaktadır. O halde bu, kanun koyucunun bilinçli bir tercihidir.

Düzenleme eleștirilmektedir. Denmektedir ki kanunun bu mantığına göre, yaralama suçuna karşı "sövmek" suretiyle tepki veren kimse şartları tamsa cezalandırılmayacak, fakat hürriyeti tahdit edilen veya cinsel

alınamaması üzerine suç tarihinde tekrar oğlu ile birlikte karakola gittiği, bu kez zorunlu müdafi ve pedagog temin edilemediğinden ifade işleminin öğleden sonra yapılacağ söylenerek bekletilmesi üzerine, atılı sözleri söylediği anlaşıldığından... cezasının TCK'nın 129/1. maddesi uyarınca takdiren 1/3 oranında indirilmesine karar verildi." Bkz. Ankara Bölge Adliyesi 6. CD, E. 2018/3858, K. 2019/1051, T. 25.04.2019 (Yayımlanmamıştır).

“...Sanı̆̆ın 'gerizekalı' şeklindeki hakaret sözünü çocuğunun damar yolunun bulunamamasından duyduğu öfke ve üzüntü ile mağdurun haksız fiiline tepki olarak söylediği değerlendirilmekle TCK'nın 129/1 ve CMK'nın 223/4-d maddeleri gereğince sanık hakkında ceza verilmesine yer olmadığına..." Bkz. Ankara Bölge Adliyesi 6. CD, E. 2019/3378, K. 2021/553, T. 24.03.2021 (Yayımlanmamıştır).

24 ARTUK - GÖKCEN, s. 533; KOCA-ÜZÜLMEZ, s. 497.

25 Nur CENTEL- Hamide ZAFER- Özlem ÇAKMUT, Kişilere Karşı İşlenen Suçlar, C. I, Beta Yayıncılık, İstanbul 2017, s. 266; TEZCAN - ERDEM - ÖNOK, s. 661. 
dokunulmazlığı ihlal edilen kimse hakaret ettiğinde ise, "takdiren" cezası azaltılarak verilecek yahut yine takdire bağlı olarak cezadan vazgeçilecektir. $\mathrm{Bu}$ durumun ceza adaleti ve hakkaniyet ile bağdaşmadığ Gerçekten de bu düşüncenin doğru olduğunu söylemek bakımından bir engel görünmemektedir. İfade edildiği gibi, bir kimsenin sadece kasten yaralama suçuna karşı hakaret fiilini gerçekleştirmesiyle bir başka ve daha ağır bir hukuki konuyu ihlal eden fiile karşı hakaret fiilini tepki olarak gerçekleştirmesi durumunda birinci halde "cezaya hükmedilmemesi" sonucu doğacakken; ikinci ve daha ağır olan diğer halde "daha az ceza" verilmesi sonucu doğacaktır.

Konunun girişinde de belirtildiği gibi, TCK m. 129/1 ve 129/2, haksız tahrikin hakaret ve sövme suçlarına özgülenmiş özel bir halidir. Bu halin uygulandığı durumlarda genel haksız tahrik hükmünün uygulanması yoluna gidilemez. Bu nedenle, yukarıda da belirtilen detaylar ile birlikte aynı şartları taşırlar. Yargıtay'ın içtihatları da bu yöndedir. Örneğin, Yargıtay 18. Ceza Dairesi, 3.3.2020 tarihli bir kararında, “...Sanığın başvuruda bulunduğu üniversitelerle mağdurun iletișime geçip olumsuz referans vererek ișini engellediğini bu nedenle, aradığında mağdurun kendisine "ben hayattayken sen hiçbir yere giremeyeceksin" şeklindeki sanık savunması araştırılarak sonucuna göre tehdit suçu yönünden TCK'nın 29. ve hakaret suçu yönünden ise anılan Kanun'un 129. maddelerinde düzenlenen haks1z tahrik hükümlerinin uygulanıp uygulanmayacağının tartışılmaması ... bozmayı gerektirir" demektedir. Yargitay'ın isabetli olarak, bu kararında aynı tahrik fiilinin arkasından bir yönden tehdit suçu bakımından "genel tahrik" hükümlerini, diğer yandan hakaret suçu bakımından özel olarak düzenlenen TCK m. 129 hükümlerinin uygulanıp uygulanmayacağının tartışılmadığını öne sürerek hüküm kurduğu görülmektedir ${ }^{26}$.

Suçu ağırlatan nedenler bakımından bu hükümlerin uygulanması hakkında, mülga kanunda "kendisine tecavüz olunan şahıs 480 . ve 482 . maddelerde yazılı cürümlere kendi haksız hareketliyle sebebiyet vermiş ise" ifadesi kullanılmakta ve böyle olunca örneğin, heyete hakaret halinde ağırlatıcı halin düzenlendiği m. 483 bakımından ve bunun dışında da özel tahkir suçları bakımından bu hükümlerden yararlanılamayacağı ifade edilmekteydi. 5237 sayılı TCK düzenlemesinde ise benzer bir hükme rastlanmamaktadir.

Suçun basit şeklini düzenleyen hüküm ile ağırlatılmış ya da hafifletilmiş şeklini düzenleyen hükümler, aynı hüküm kapsamında kabul edildiğinden

26 Yargitay 18. CD, E. 2020/765, K. 2020/5438, T. 3.3.2020 (kazanci.com). 
mümkün olabildiği ölçüde, hakaret suçlarına özgülenen bu özel tahrik hallerinden suçun ağırlatılmış hallerinde de yararlanılabilmesinin önünde bir engel yoktur.

$\mathrm{Bu}$ düzenlemeler, doktrinde farklı düşünceler olsa $\mathrm{da}^{27}$ bir hukuka uygunluk nedeni olmayıp sadece suça etki eden bir neden olarak karşımıza çıkmakta; genel haksız tahrikte cezayı azaltıcı neden ne ise, özel tahrik halinde de o olmaktadir ${ }^{28}$.

Sonuç olarak, haksız tahrikin bu özel hallerinden de (gerek birinci fikra gerek ikinci fikra düzenlemesinden olarak) bahsedebilmek için; tekrara düşmemek adına yukarıda belirtilen şartları da taşıması kaydıyla, ortada bir haksız fiil olmalıdır ve bu fiilin etkilerinin kişi üzerinde devam etmesi gerekmektedir ${ }^{29}$. Eğer bu etki ortadan kalkarsa artık bu halden yararlanmak mümkün görünmez. Ancak doktrinde genel tahrikten farklı olarak haksız hakaretin failde gerçek anlamda tepki yahut elem yahut öfke meydana getirdiğinin araştırılmasına gerek olmadığı düşüncesinin savunulduğu da görülmektir ${ }^{30}$. Bu düşünceye katılmak, haksız tahrik kurumunun yapısı bakımından mümkün görünmemektedir.

\section{TCK m. 129/3 Hükmünde Yer Verilen Düzenleme Bağlamında Hakaret Suçunun Karşılıklı Olarak İşlenmesi}

Karşı1ıklı hakaret yahut doktrindeki diğer adıyla karşılıklı tahkir, TCK m. 129/3'de "Hakaret suçunun karş1lkklı olarak işlenmesi halinde, olayın mahiyetine göre, taraflardan her ikisi veya biri hakkında verilecek ceza üçte birine kadar indirilebileceği gibi, ceza vermekten de vazgeçilebilir." şeklinde hüküm altına alınmıştır.

Karşılıklı hakaret ve sövme, yapısı itibariyle 765 sayılı Kanundan çok da farklı olmadığı görülmektedir. Bazı sözcük tercihleri dışında yapı olarak karşılıklı tahkire ilişkin maddenin neredeyse aynı olduğunu söylemek mümkündür. Aradaki tek fark, 765 sayılı Kanunda "hangi tarafın sebebiyet verdiğini nazara alarak yalnız biri hakkında cezayı sskat edebilir" ifadesidir. 5237 sayılı Kanunda bu durum "olayın mahiyetine göre her ikisi veya biri

27 ERMAN, Hakaret ve Sövme Suçları, s. 220 vd.

28 Timur DEMIRBAŞ, Türk Ceza Kanunu'nda Özel Tahrik Halleri, Üçdal Neşriyat, İstanbul 1985, s. 37, 146.

29 HAFIZOĞULLARI - ÖZEN, Özel Hükümler Kişilere Karşı Suçlar, s. 246. Karş. Devrim AYDIN, “Türk Ceza Hukuku'nda Hakaret Suçu”, Prof. Dr. Nur CENTEL'e Armağan, MÜHF Hukuki Araştırmalar Dergisi Özel Sayı, Y. 2013, C. 19, S. 2, ss. 879 - 919.

30 TEZCAN - ERDEM - ÖNOK, s. 625. Karş. Veli Özer ÖZBEK - Koray DOĞAN - P1nar BACAKSIZ, Türk Ceza Hukuku Özel Hükümler, Seçkin Yayıncılık, Ankara 2020, s. 528. 
hakkında ceza indirilebilir veya vermekten de vazgeçilebilir" şeklinde ifade edilmektedir. Görüldüğü gibi mülga kanunda, "sebep olan tarafın" bu nedenselliğinin nazara alınması istenmektedir. 5237 sayılı TCK' da ise bu durum "olayın mahiyetine göre" biçiminde ifade edilmektedir ${ }^{31}$.

Hakaretin karşılıklı olmasında esas aranması gereken nedensellik bağıdır. Böyle olunca ilk hakaret ile bu hakarete tepki olarak işlenen hakaret arasında bir bağ olması gerekmektedir. Doktrinde bir görüşe göre, ilk ve ikinci hareket arasında "zaman ve yer" bakımından bir bağıntı olması gerekmez; aranması gereken bu hareketlerin arasında psikolojik bir bağın olmasidir ${ }^{32}$.

Zanardelli Kanunu gibi 765 sayılı TCK'da da konu hakkında üç yaklaşım olduğu bilinmektedir ${ }^{33}$. Zanardelli'nin, karşl1ıklı hakaret halini, medeni hukuk ve Roma ceza hukukundaki "takas" teorisinin ceza hukukunda uygulanması olarak gördüğü ve bu düşünceye dayandığı ifade edilmektedir. Manzini'ye atfedilen ${ }^{34}$ diğer düşünceye göre, takas halinde "karşılıklı tam bir eşitlik aranması" gerekir; ancak kanunda bu eşitlik aranmamıştır. Kanunda karşılık vermekte aşırıya kaçılmış olsa bile eşitliği örtülü de olsa işaret edecek bir tabir görünmemektedir. Carrara ve Maggiore'ya atfedilen görüşe göre, kurumun temelini karşıllklı tahkir halinde şikayet veya davadan zımnen vazgeçilmiş olması görüşünde aramak gerekir. Öyle ki, tahkire karş1lk veren kimse böyle yaparak hakaret ve sövme fiili işleyen fail aleyhine şikayet etmek hakkını kaybetmiştir. Kusurluluğu özel kastta arayan Florian'a göre ise, ortada bir "karş1lı verme kastı" vardır, o halde manevi unsur yoktur. Bu görüş, karşılıkta bulunanın

31 Ayrıntılı bilgi için bkz. Muharrem ÖZEN, "Hakaret ve Sövme Suçlarında Özel Tahrik Halleri", TBBD, Y. 2002, C. 51, S. 3, s. 37.

32 TEZCAN - ERDEM - ÖNOK, s. 629; CENTEL-ZAFER-ÇAKMUT, s. 268.

“...Sanığın katılanın kendisine yönelik 'anlamıyor gerizekalı' şeklinde sözü üzerine atılı sözleri söylediğine ilişkin savunması, iddiayı teyit eden özel güvenlik görevlisi tanığın barışmalar üzerine doktor odasına gittiğine ilişkin açıklamalarına göre olay başlangıcının tanık tarafından duyulmadığı ve savunmayı teyit eden tanığın anlatımları, katılanla ilgili ek kovuşturmaya yer olmadığına dair karardaki açıklamalar ile hakaret suçunun işlendiği doktor muayene odasına ilişkin görüntü bulunmayan CD'nin ses kaydı içermemesine göre, sanığın üzerine atılı hakaret suçuna konu sözleri sarfettiği ancak aksi kanıtlanamayan savunmaya itibarla "şüpheden sanık yararlanır" ilkesi de gözetilerek ilk hakaretin katılandan geldiğinin kabulü ile sanık hakkında ceza verilmesine yer olmadığına..." Bkz. Ankara Bölge Adliyesi 6. CD, E. 2019/1881, K. 2020/1959, T. 14.10.2020 (Yayımlanmamıştır).

33 ERMAN, Hakaret ve Sövme, s. 212.

34 ERMAN, Hakaret ve Sövme, s. 211. 
cezalandırılmamasını izah etse de, her iki tarafın cezasız kalmasının nedenini açıklayamadığı gerekçesiyle eleştirilmiştir ${ }^{35}$.

Yukarıdaki açıklamalarla birlikte değerlendirildiğinde, bu kurumun hukuki niteliğini ceza politikası ile açıklayan yaklaşım bizce de daha isabetli görünmektedir.

Sonuç olarak, karşılıklı hakaretten bahsedilebilmesi için, mutlaka ilk hareketin haksız olması, buna karşılık gerçekleştirilen hareket ile ilk hakaret arasında nedensellik bağı bulunması gerekmektedir ${ }^{36}$. Böyle olunca hakaret suçu dışındaki suçlarda, fiiller karşılıklı olsa da bir karşılıklı hakaret bağlamında düzenlenen bu halin varlığından bahsetmek mümkün görünmemektedir. Zira kanun koyucu bu normu salt hakaret suçuna özgülemektedir. Nitekim Yargıtay' $1 n^{37}$ uygulamasının bu yönde olduğu görülmektedir. Gerçekten de 10.2.2020 tarihli bir kararında, "Olay günü alkollü araç kullanan sanık ... ve temyiz dışı sanık ... arasında seyir halinde iken tartışma ve küfürleşmelerin yaşanması, ayrıca mahkemece temyiz dışı sanıklar ... ile A. A. hakkında karş11ıklı hakaret nedeniyle ceza verilmesine yer olmadığına karar verilmesi karşısında, olayın çıkış nedeni ve gelişmesi değerlendirilerek sonucuna göre tehdit ve yaralama suçları yönünden TCK'nın 29, hakaret suçu yönünden ise anılan Kanunun 129. maddesinde düzenlenen haksız tahrik hükümlerinin uygulanıp uygulanmayacağının tartışılmaması ..." diyerek, karşılıklı hakaret nedeniyle TCK m. 129/3 gereği ceza verilmesine yer olmadığına hükmedilse de, tehdit suçu bakımından muhakkak haksız tahrikin genel hükümlerdeki düzenlemesi olan TCK m. 29 tartışılmadan hüküm kurulmasını doğru olarak bozma sebebi yaptığı görülmektedir.

35 ERMAN, Hakaret ve Sövme, s. 211.

6 ÖZBEK - DOĞAN - BACAKSIZ, Özel Hükümler, s. 531.

37 Yargitay 4. CD, E. 2019/7695, K. 2020/2726, T. 10.2.2020 (kazanci.com). 


\section{KAYNAKÇA}

ARTUK, Mehmet Emin/ GÖKCEN, Ahmet, Ceza Hukuku Özel Hükümler, Adalet Yayınevi, Ankara 2017.

AYDIN, Devrim, “Türk Ceza Hukuku'nda Hakaret Suçu”, Prof. Dr. Nur CENTEL'e Armağan, MÜHF Hukuki Araştırmalar Dergisi Özel Sayı, Y. 2013, C. 19, S. 2, ss. $879-919$.

CENTEL, Nur/ ZAFER, Hamide/ ÇAKMUT, Özlem, Kişilere Karşı İşlenen Suçlar, C. I, Beta Yayıncılık, İstanbul 2017.

DEMİRBAŞ, Timur, Türk Ceza Kanunu'nda Özel Tahrik Halleri, Üçdal Neşriyat, İstanbul 1985.

DEMİRBAŞ, Timur, Haksız Tahrik, Seçkin Yayınevi, Ankara 2021.

DÖNMEZER, Sulhi/ ERMAN, Sahir, Nazari ve Tatbiki Ceza Hukuku (Genel Kisım) C. II, Sulhi Garan Matbaasi, B. 11, İstanbul 1997.

EREM, Faruk, Adalet Psikolojisi, AÜHF Yayınları, Yayın No. 161, 4. Baskı, Ajans - Türk Matbaası, Ankara 1961.

EREM, Faruk, Hakaret ve Sövme, Ankara Üniversitesi Hukuk Fakültesi Yayınları: No. 127, Güzel İstanbul Matbaası, Ankara 1958.

EREM, Faruk, Türk Ceza Hukuku Özel Hükümler, C. IV, 3. Baskı, Seçkin Kitabevi, Ankara 1985.

ERMAN, Sahir, Hakaret ve Sövme Suçları, İstanbul Üniversitesi Fen Fakültesi Döner Sermaye İşletmesi Prof. Dr. Nazım Terzioğlu Basım Atölyesi, 2. Baskı, İstanbul 1989.

ERMAN, Sahir/ ÖZEK, Çetin, Ceza Hukuku Özel Bölüm Kişilere Karşı İşlenen Suçlar, Dünya Yayıncılık, İstanbul 1995.

HAFIZOĞULLARI，Zeki/ ÖZEN, Muharrem, Türk Ceza Hukuku Genel Hükümler, US-A Yayıncılık, Ankara 2018.

HAFIZOĞULLARI, Zeki/ ÖZEN, Muharrem, Türk Ceza Hukuku Özel Hükümler Kişilere Karşı Suçlar, US-A Yayıncılık, Ankara 2016.

KOCA, Mahmut/ ÜZÜLMEZ, Mahmut, Türk Ceza Hukuku Özel Hükümler, Adalet Yayinevi, Ankara 2019.

ÖZBEK, Veli Özer/ DOĞAN, Koray/ BACAKSIZ, Pınar/ TEPE, İlker, Türk Ceza Hukuku Genel Hükümler, Seçkin Yayıncılık, 11. Baskı, Ankara 2020.

ÖZBEK, Veli Özer/ DOĞAN, Koray/ BACAKSIZ, Pınar, Türk Ceza Hukuku Özel Hükümler, Seçkin Yayıncılık, Ankara 2020.

ÖZEN, Muharrem, "Hakaret ve Sövme Suçlarında Özel Tahrik Halleri", TBBD, Y. 2002 , C. 51 , S. 3 , ss. $27-49$.

ÖZEN, Mustafa, Ceza Hukuku Özel Hükümler Dersleri, Adalet Yayınevi, Ankara 2019.

TEZCAN, Durmuş/ ERDEM, Mustafa Ruhan/ ÖNOK, Murat, Teorik ve Pratik Ceza Özel Hukuku, Seçkin Yayınevi, Ankara 2018.

TOROSLU, Nevzat, Ceza Hukuku Özel Kısım, Savaş Yayınevi, Ankara 2019. 